\title{
PEMELIHARAAN INDUK IKAN TUNA SIRIP KUNING, Thunnus albacares DALAM BAK TERKONTROL
}

\author{
Jhon Harianto Hutapea, Gusti Ngurah Permana, dan Ananto Setiadi
}

Balai Besar Riset Perikanan Budidaya Laut

J. Br. Gondol, Kec. Gerokgak, Kab. Buleleng, Kotak Pos 140, Singaraja-Bali 81101

E-mail: rimena1711@yahoo.com

(Naskah diterima: 9 September 2009; Disetujui publikasi: 26 April 2010)

\begin{abstract}
ABSTRAK
Intensifikasi penangkapan ikan tuna baik yang langsung dipasarkan maupun dibesarkan dalam usaha budidaya, berpengaruh negatif terhadap kelestarian populasi ikan ini di alam. Dengan demikian upaya perbenihan secara buatan perlu dilakukan untuk mengurangi tekanan terhadap populasi alam. Balai Besar Riset Perikanan Budidaya Laut, Gondol telah merintis perbenihan ikan tuna sirip kuning (Thunnus albacares) sejak tahun 2003 bekerjasama dengan Overseas Fishery Cooperation Foundation (OFCF) Jepang. Induk ikan tuna telah berhasil dibesarkan dan dipijahkan dalam bak beton bervolume $1.500 \mathrm{~m}^{3}$ secara terkontrol, dengan sistem pergantian air semi tertutup. Pakan yang diberikan berupa ikan layang dan cumi-cumi sekitar $2,5 \%$ biomassa per hari. Pemijahan pertama terjadi pada bulan Oktober tahun 2004, ukuran induk diperkirakan lebih dari $9,138 \mathrm{~kg}$ atau panjang cagak lebih dari $82 \mathrm{~cm}$ dengan perkiraan umur sekitar 2 tahun. Puncak pemijahan terjadi pada tahun 2005 dan 2006 dengan frekuensi pemijahan masing-masing lebih dari 100 kali. Pemeliharaan induk ikan tuna dengan kepadatan $0,66 \mathrm{~kg} / \mathrm{m}^{3}$ belum dapat dikatakan sebagai kepadatan maksimum dan peningkatan kematian cenderung akibat ruang gerak yang semakin sempit seiring dengan pertumbuhan induk. Namun demikian kendala yang ditemukan dalam pemeliharaan induk adalah kematian akibat menabrak dinding bak sedangkan kendala dalam pemeliharaan larva adalah serangan endoparasit pada telur.
\end{abstract}

KATA KUNCl: perbenihan, induk ikan, tuna sirip kuning, endoparasit

ABSTRACT: Rearing of yellowfin tuna, Thunnus albacares in controlled tank. By: Jhon Harianto Hutapea, Gusti Ngurah Permana, and Ananto Setiadi

Escalation on tuna capture fisheries production for market needs and tuna fish culture has profoundly affected its long term wild stock sustainability. Then, the efforts on breeding program for this species is necessary to reduce pressure on its natural population. Research Institute for Mariculture, Gondol-Bali started yellowfin tuna (Thunnus albacares) breeding program since 2003 in collaboration with Overseas Fishery Cooperation Foundation (OFCF), Japan. Tuna broodstock were successfully reared and spawned naturally in a concrete tank with volume of 1,500 $\mathrm{m}^{3}$ equipped with semi-closed water circulation system. Fish were fed with scads mackerel and squid at 2.5\% of fish biomass per day. First spawning happened in 2004 with broodstock size at first maturation was estimated about $9.138 \mathrm{~kg}$ of body weight or about $82 \mathrm{~cm}$ of fork length and 2 years old. The highest spawning productivity of broodstock was taking place in 2005 and 2006 with spawning frequency of more than 100 times. Aside of the success in spawning, fish mortality caused by its behavior of striking tank's wall is still remain a problem along with endo-parasite infection on the eggs. In addition, rearing of yellowfin tuna broodstock at a density of $0.66 \mathrm{~kg} / \mathrm{m}^{3}$ has not been 
accepted as an optimal density and broostock mortality is predicted to increase due to space limitation in the tank as the fish grow larger.

KEYWORDS: broodstock, yellowfin tuna, rearing, captivity

\section{PENDAHULUAN}

Penangkapan berbagai spesies ikan tuna untuk dikonsumsi oleh manusia sudah lama dikenal dan saat ini intensitasnya sudah sangat tinggi. Bahkan diperkirakan sudah melampaui batas lestari. Penurunan populasi alam ini dapat terlihat dari terjadinya penurunan hasil tangkap per satuan usaha dan juga penurunan ukuran ikan yang tertangkap (Batubara, 2003). Budidaya ikan tuna di jaring apung mulai diupayakan terutama di Jepang sejak tahun 1970, dengan membentang jaring di perairan teluk (Masuma \& Oka, 1997). Dengan teknik sama, sejak tahun 1975, telah dilakukan penangkapan dan pemeliharaan ikan tuna sirip biru yang setelah memijah bermigrasi memasuki perairan Kanada untuk penggemukan (Farwell, 2001). Saat ini sudah banyak negara yang berhasil dalam usaha penggemukan/budidaya ikan tuna seperti di Mediterania, Australia, dan Mexico. Ikan tuna yang dibudidayakan masih terbatas pada jenis ikan tuna sirip biru Pacific (T.orientalis dan $T$. thynnus) di Jepang serta Eropa, dan Tuna sirip biru selatan (T. maccoyii) di Australia. Dengan semakin intensifnya penangkapan ikan tuna di alam baik yang langsung dipasarkan maupun dibesarkan dahulu dalam usaha budidaya, akan berpengaruh negatif terhadap kelestariannya. Dengan demikian upaya perbenihan ikan tuna secara buatan perlu dilakukan untuk mengurangi tekanan terhadap populasi alamnya.

Jepang telah berhasil memijahkan ikan tuna sirip kuning ( $T$. albacares) maupun tuna sirip biru Atlantic ( $T$. orientalis) walaupun tingkat keberhasilannya masih dalam skala yang kecil. Selain itu, di Universitas Kinki Jepang juga telah berhasil memijahkan anak dari induk alam (close cycle-satu siklus kehidupan lengkap). Proyek bersama negara-negara Eropa yang berlokasi di Spanyol juga telah melaporkan keberhasilan memijahkan ikan tuna sirip biru Atlantik pada tahun 2005 (Anonimous, 2005) namun belum berhasil dalam pembenihannya.

Pemeliharaan induk yang dilakukan dalam jaring apung di laut sangat tergantung kepada musim. Mengingat banyaknya keterbatasan dalam melakukan riset pada induk-induk yang dipelihara dalam jaring-jaring tersebut, maka OFCF Jepang bekerja sama dengan pemerintah Panama telah merintis riset perbenihan ikan tuna sirip kuning dengan menggunakan bak beton sebagai wadah pemeliharaan induk (Mergulies et al., 2009). Riset dilanjutkan dengan sistem yang sama dengan bekerjasama antara OFCF Jepang dan Pemerintah Indonesia. Diharapkan dengan memelihara induk dalam bak beton dengan sistem pergantian air yang lebih baik, induk akan dapat memijah dengan baik. Selanjutnya Australia juga telah melaporkan keberhasilan pemijahan induk ikan tuna sirip biru selatan (T. maccoyii) dalam bak beton pada tahun 2005 (Anonimous, 2005).

Tulisan ini merupakan rangkuman hasil riset perbenihan ikan tuna sirip kuning ( $T$. albacares) yang dilakukan di Indonesia sejak 2003-2008 yang bertujuan untuk mengetahui teknik pemeliharaan induk ikan tuna sirip kuning dalam bak terkontrol.

\section{BAHAN DAN METODE}

Calon induk diperoleh dari hasil penangkapan di perairan lepas Pantai Bali Utara. Calon induk yang tertangkap berukuran 2-5 kg dengan metode penangkapan dan transportasi mengikuti Hutapea et al. (2003). Ikan-ikan hasil tangkapan baik jantan maupun betina terlebih dahulu dipelihara dalam bak aklimatisasi (volume: $235 \mathrm{~m}^{3}$ ) (Hutapea, 2007), kemudian dipindah ke dalam bak pemeliharaan induk (volume : $1.525 \mathrm{~m}^{3}$ ), setelah terlebih dahulu dilakukan pengukuran panjang ikan, pengambilan sampel sirip untuk keperluan analisis DNA dan penandaan dengan microchips tagging sebagai identitas individu ikan.

Dalam pemeliharaan calon induk dan induk ikan tuna sirip kuning, air laut yang digunakan dialirkan dengan sistem bejana berhubungan melalui 2 buah pipa yang dipasang di atas permukaan dasar laut sepanjang 250 meter ke sumur. Tiga buah pompa berkapasitas 7,5 HP dengan debit $1 \mathrm{~m}^{3} /$ menit, digunakan untuk memompa air dari sumur ke tower penampungan setelah melalui saringan pasir 
bertekanan tinggi (HPF Model ASF-F2). Kemudian air disalurkan ke bak-bak penelitian secara gravitasi. Selanjutnya, air dari dalam bak bagian dasar disedot dengan menggunakan 2 pompa berkapasitas 2,5 HP dengan debit 0,4 $\mathrm{m}^{3} /$ menit ke bak sand filter yang terletak lebih tinggi dari bak penelitian dan dari sana air tersebut dialirkan melalui dua pipa PVC berdiameter 8 inci lalu kembali ke bak penelitian secara gravitasi. Dengan sistem sirkulasi semi tertutup ini, pergantian air setiap hari diperhitungkan sekitar 50\% air laut melalui saringan pasir bertekanan tinggi dan 50\% air resirkulasi melalui saringan pasir (biofilter) lalu kembali ke dalam bak pemeliharaan. Ketinggian air di dalam bak diatur melalui bak pembuangan sekaligus sebagai bak tempat kolektor telur pada dinding luar bak utama dengan sistem air melimpah (over flow) melalui bak kontrol dengan menggunakan pipa PVC 8 inci.

Untuk menjaga agar ketersediaan oksigen terlarut di dalam air selalu optimum, setiap bak dilengkapi dengan 3 buah saluran aerasi yang diletakkan di dasar bak dan udara disuplai melalui blower (Mitsubishi, Type SF.HRCAO, 3,7 KW). Pengelolaan kualitas air dilakukan dengan pengontrolan suhu, $\mathrm{pH}$, dan oksigen terlarut dalam bak setiap hari dan pembersihan saringan pasir bertekanan tinggi, saringan pasir pada bak resirkulasi secara periodik. Untuk membersihkan kotoran yang ada di dasar bak setiap 2 minggu sekali dilakukan penyiponan dengan menggunakan tenaga penyelam.

Pemeliharaan calon induk dilakukan dengan pemberian pakan yang terdiri atas ikan layang dan cumi-cumi sebesar $2,5 \%$ biomassa per hari dengan rasio $1: 1$. Pemberian pakan dilakukan setiap hari pada pagi hari kecuali hari minggu ikan dipuasakan. Untuk meningkatkan kesehatan dan mempercepat kematangan gonad, setiap pemberian pakan dilakukan penambahan vitamin mix $(40 \mathrm{~g})$ dan vitamin C (7 g) serta ditambah vitamin $\mathrm{E}(14 \mathrm{~g})$ setiap hari pada minggu pertama dan ketiga. Pemberian vitamin didasarkan pada jumlah dan biomassa induk, di mana campuran vitamin ini dimasukkan ke dalam kapsul (100 kapsul) lalu disisipkan dalam pakan.

Pengamatan harian yang dilakukan meliputi aktivitas makan ikan, kesehatan ikan, dan jumlah pakan yang dimakan dan parameter kualitas air. Pengamatan tingkah laku pemijahan induk meliputi waktu dan frekuensi pemijahan serta jumlah telur per pemijahan. Pengukuran panjang-bobot, jenis kelamin, bobot gonad, dan hati serta pengamatan penyebab kematian ikan juga dilakukan. Biomassa ikan dalam bak diestimasi berdasarkan pertumbuhan ikan dalam bak melalui pengukuran panjang dan bobot ikan yang mati selama pemeliharaan.

\section{HASIL DAN BAHASAN}

\section{Pemeliharaan Induk dan Pemberian Pakan}

Pemeliharaan induk dimulai pada bulan September 2003 dengan jumlah 27 ekor dan terus meningkat hingga 40 ekor pada akhir tahun. Kemudian selama tahun 2004 terdapat fluktuasi jumlah induk sebagai akibat adanya kematian dan penambahan calon induk hasil tangkapan dari alam. Tahun 2005, sejalan dengan peningkatan ukuran induk, ada kecenderungan terjadinya peningkatan kematian, sementara penambahan calon induk semakin berkurang sehingga pada akhir tahun jumlah induk hanya 19 ekor. Tahun-tahun berikutnya, hampir tidak ada penambahan induk sehingga jumlah induk semakin berkurang dan hanya tersisa 7 ekor pada tahun 2008. Data Jumlah induk ikan tuna sirip kuning ( $T$. albacares) dari tahun 2003-2006 terlihat pada Gambar 1.

Calon induk yang ditransfer ke dalam bak induk diberi pakan dua kali sehari yaitu pagi dan sore. Berdasarkan pengamatan, jika nafsu makan ikan pada pagi hari rendah maka biasanya pada sore hari akan meningkat. Setelah ikan mencapai bobot sekitar $10 \mathrm{~kg}$, pemberian pakan hanya diberikan satu kali saja. Selama induk belum memijah, ikan diberi pakan pada sore hari tetapi setelah memasuki musim pemijahan, pemberian pakan dilakukan pada pagi hari. Hal ini dilakukan agar kualitas air pada sore harinya, sebelum ikan memijah sudah kembali baik.

Jumlah pakan harian induk ikan tuna bervariasi tergantung pada ukuran induk. Semakin banyak induk dan semakin besar induk, kebutuhan pakannya semakin meningkat. Namun ditinjau dari efisiensi pemberian pakan pada ikan tuna sirip kuning dalam penelitian ini, tidak terlihat adanya perbedaan yang nyata antara jumlah induk dengan rata-rata waktu yang dibutuhkan untuk memanfaatkan pakan yang diberikan (Tabel 2 ). Data ini menunjukkan bahwa, walaupun jumlah induk ikan tuna sirip kuning sudah sedikit, tetapi nafsu makannya masih tetap tinggi. 


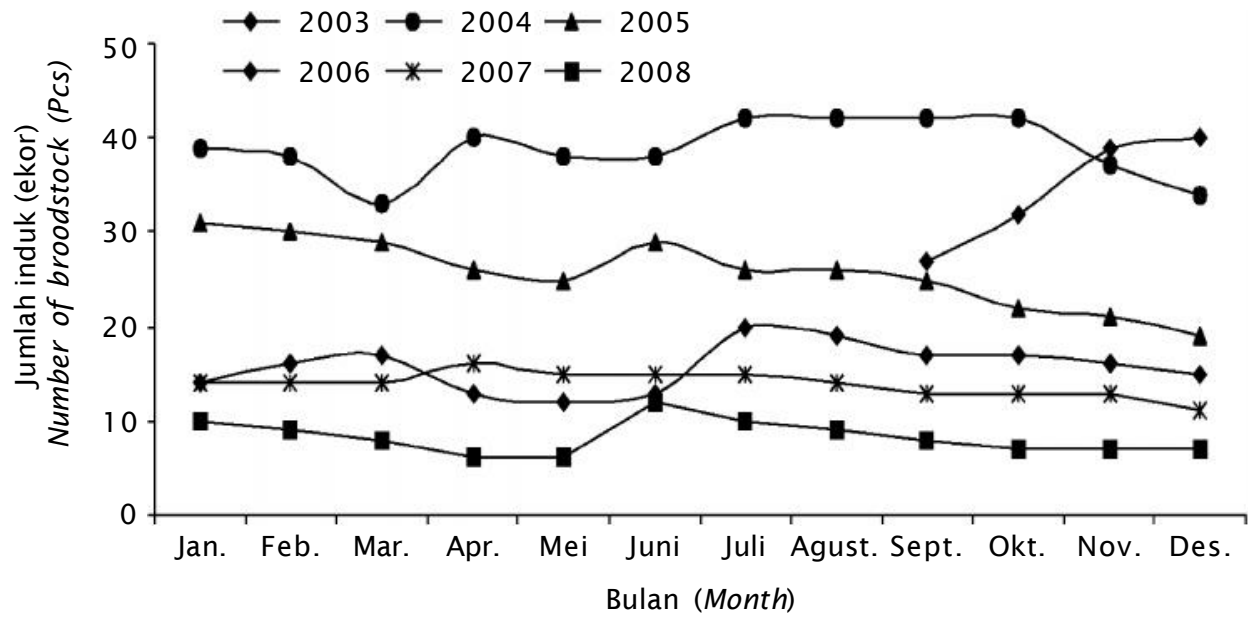

Gambar 1. Jumlah induk ikan tuna sirip kuning (Thunnus albacares) yang dipelihara dalam bak beton dalam kurun waktu 2003-2008

Figure 1. Number of yellowfin tuna (Thunnus albacares) broodstock in captivity from 2003 to 2008

Dari Gambar 2, dapat dilihat bahwa pada awal pelaksanaan riset pada tahun 2003, jumlah ikan yang ditransfer ke dalam bak pemeliharaan sebanyak 50 ekor dengan tingkat kematian kurang dari 10 ekor. Tahun 2004-2006 masih dapat dilakukan penambahan calon induk sebanyak 12-18 ekor, namun dalam waktu yang sama, tingkat kematian induk juga meningkat dengan nilai rata-rata $23 \pm 2,6$ ekor per tahun. Hal inilah yang menyebabkan jumlah induk terus berkurang dalam bak pemeliharaan. Kendala yang sering ditemui dalam pemeliharaan ikan tuna sirip kuning dalam bak beton adalah kematian akibat menabrak dinding bak (Hutapea, 2007). Sebagian besar ikan yang menabrak dinding langsung mati sedangkan sebagian lagi mengalami stres dan beberapa

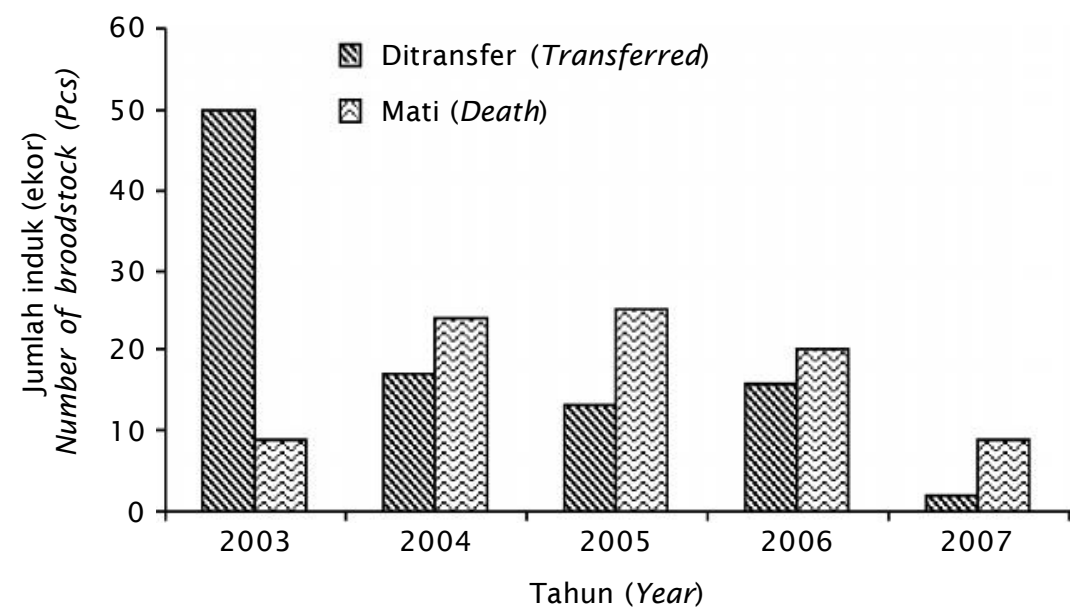

Gambar 2. Jumlah calon induk ikan tuna sirip kuning (Thunnus albacares) yang ditransfer ke dalam bak induk dan jumlah induk yang mati dalam kurun waktu 2003-2007

Figure 2. Number of yellowfin tuna (Thunnus albacares) broodstock candidates transferred into broodstock tank and number of broodstock died in captivity during 2003-2007 


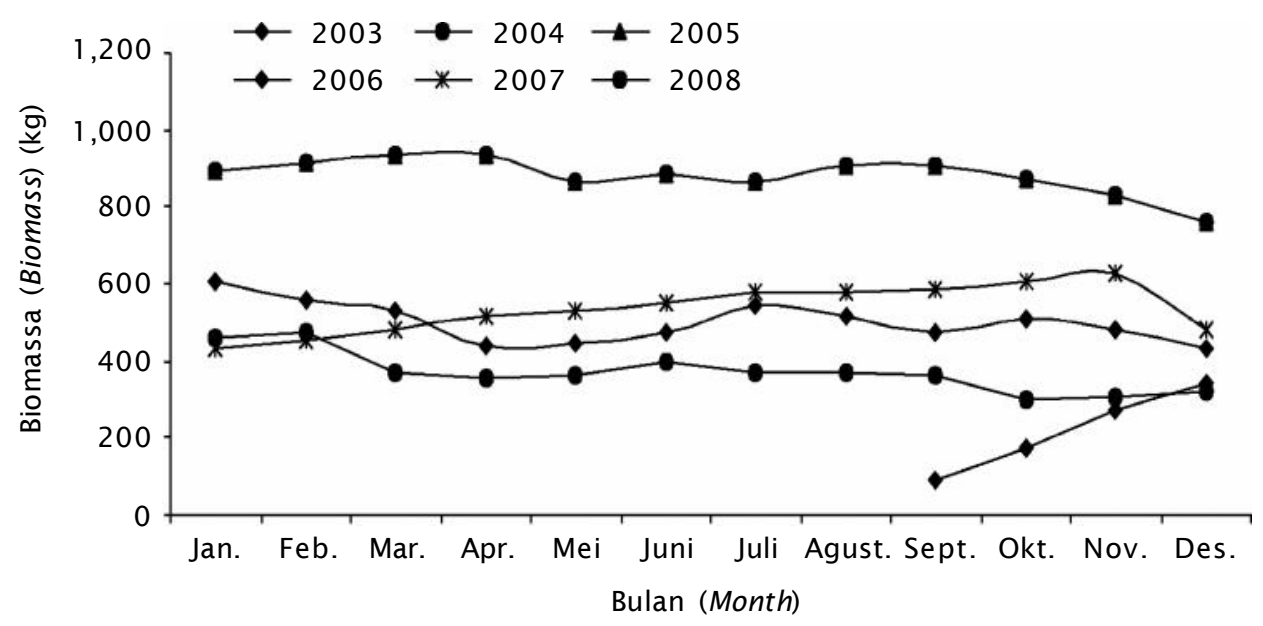

Gambar 3. Estimasi biomassa induk ikan tuna sirip kuning (Thunnus albacares) yang dipelihara dalam bak beton dalam kurun waktu 2003-2008

Figure 3. Biomass estimation of Yellowfin tuna (Thunnus albacares) broodstock in captivity during 2003-2008

hari tidak mampu untuk makan sampai akhirnya mati.

Dari data pengukuran panjang dan bobot ikan, serta tagging setiap individu dengan menggunakan microchips tagging pada awal penelitian, maka biomassa ikan yang ada dalam bak dapat diestimasi berdasarkan nilai rata-rata pertumbuhan ikan yang mati akibat menabrak dinding (Tabel 1). Biomassa ikan pada tahun 2003 berkisar antara 100-350 kg, dan meningkat hingga $1.000 \mathrm{~kg}$ pada akhir tahun 2004 sejalan dengan pertumbuhan ikan. Tahun 2005, biomassa ikan berkisar antara 750-900 $\mathrm{kg}$, terjadi penurunan karena kematian ikan juga berpengaruh terhadap biomassa. Tahun 2006 dan 2007 biomassa ikan diperkirakan hanya $400-600 \mathrm{~kg}$, dan terus menurun hingga tahun 2008 yaitu sekitar 300 kg. (Gambar 3). Penurunan biomassa ini, terjadi karena adanya kematian induk dan tidak diimbangi dengan penambahan induk.

Ditinjau dari kapasitas bak dalam menampung ikan, menurut Masuma-JASFA Jepang (personal com., 2003), kepadatan maksimum ikan tuna untuk tujuan pemijahan adalah $0,5 \mathrm{~kg} / \mathrm{m}^{3}$. Dengan demikian dalam bak bervolume $1500 \mathrm{~m}^{3}$ yang digunakan di BBRPBL Gondol, secara teoritis, kepadatan maksimum adalah $750 \mathrm{~kg}$. Namun berdasarkan data pada Gambar 3 terlihat pada pertengahan tahun 2004 hingga tahun 2005, biomassa ikan yang ada dalam bak induk sudah di atas kepadatan maksimum, di mana ukuran ikan berkisar antara $20-40 \mathrm{~kg}$ /ekor dengan jumlah di atas 20 ekor. Setelah mengamati jumlah dan biomassa ikan tuna yang dipelihara, ternyata walaupun pada kurun waktu tersebut kepadatan ikan telah melampaui $0,5 \mathrm{~kg} / \mathrm{m}^{3}$, tidak ada kecenderungan peningkatan kematian ikan dengan meningkatnya jumlah karena ukuran ikan masih relatif kecil. Tetapi ketika ukuran ikan semakin besar dan meningkatnya jumlah dan biomassa ikan tingkat kematian cenderung meningkat (Gambar 1 dan 2). Kepadatan yang pernah dicapai dalam pemeliharaan ikan tuna sirip kuning dalam penelitian ini mencapai $0,66 \mathrm{~kg} / \mathrm{m}^{3}$ belum dapat dikatakan sebagai kepadatan maksimum. Hal yang sama juga diperoleh dari penelitian pada ikan dan bak yang sama di Panama namun setelah mencapai kepadatan $0,64 \mathrm{~kg} / \mathrm{m}^{3}$ ada kecenderungan terjadi penurunan pertumbuhan ikan (Wexler et al., 2003). Sebaliknya, walaupun kepadatannya masih di bawah optimum, ketika ruang gerak semakin sempit seiring dengan pertumbuhan induk yang semakin panjang dan gemuk maka tingkat kematian meningkat.

Ditinjau dari efisiensi pemberian pakan pada ikan tuna sirip kuning dalam penelitian ini, jumlah pakan yang dimakan sangat bervariasi, yang tergantung pada ukuran dan jumlah ikan. Namun demikian, tidak terlihat adanya perbedaan yang nyata antara jumlah 


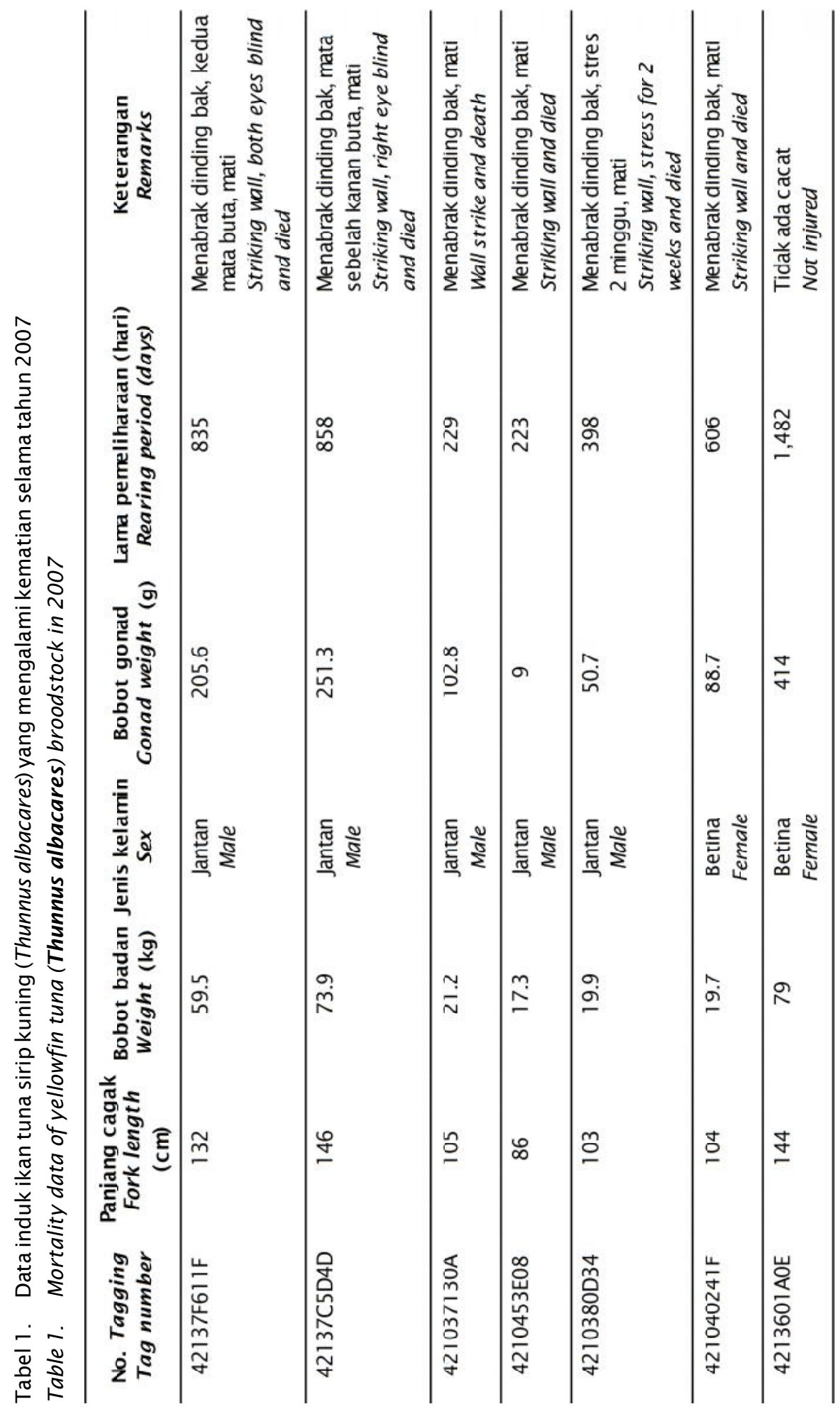


Tabel 2. Perbandingan jumlah induk, pakan, dan waktu rata-rata yang dibutuhkan untuk menghabiskan pakan yang diberikan

Table 2. Comparison among number of broodstock, the amount of feed consumed and mean of feeding period

\begin{tabular}{ccccc}
\hline \multirow{2}{*}{$\begin{array}{c}\text { Jumlah induk (ekor) } \\
\text { Number of } \\
\text { broodstock (pcs) }\end{array}$} & $\begin{array}{c}\text { Jumlah pakan } \\
\text { per hari } \\
\text { Amount of feed } \\
\text { per day (kg) }\end{array}$ & $\begin{array}{c}\text { Waktu pemberian pakan (menit) } \\
\text { Feeding period (minut es) }\end{array}$ \\
\cline { 3 - 5 } & $\begin{array}{c}\text { Rata-rata } \\
\text { Mean }\end{array}$ & $\begin{array}{c}\text { Paling cepat } \\
\text { Fast est }\end{array}$ & $\begin{array}{c}\text { Paling lambat } \\
\text { Slowest }\end{array}$ \\
\hline $40-50$ & $7-28$ & 3.29 & 1.00 & 6.00 \\
$30-40$ & $15-25$ & 2.20 & 1.00 & 5.00 \\
$20-30$ & $15-25$ & 3.43 & 1.00 & 7.00 \\
$10-20$ & $16-19$ & 3.09 & 1.00 & 6.00 \\
$<10$ & $5-10$ & 2.47 & 1.00 & 3.00 \\
\hline
\end{tabular}

induk dengan rata-rata waktu yang dibutuhkan untuk memanfaatkan pakan yang diberikan (Tabel 2). Hal ini memberikan gambaran bahwa ikan tuna sangat responsif terhadap pakan yang diberikan.

\section{Sistem Pengelolaan Kualitas Air}

Pemeliharaan ikan tuna di dalam bak beton dengan sistem pergantian air yang semi tertutup, diharapkan tidak terjadi perubahan faktor-faktor fisika-kimia air secara drastis. Beberapa faktor kualitas air yang paling berpengaruh terhadap kelangsungan hidup ikan tuna adalah suhu, salinitas, oksigen terlarut, dan $\mathrm{pH}$ air. Selama pemeliharaan, keempat faktor tersebut diukur setiap hari dan nilai rata-ratanya disajikan pada Gambar 4, 5, dan 6.

\section{Salinitas}

Salinitas air laut dalam bak pemeliharaan berkisar antara 32-34 ppt, masih layak bagi pertumbuhan ikan tuna sirip kuning. Secara umum, salinitas air laut sedikit lebih rendah pada bulan-bulan Maret hingga Juni, namun demikian tidak menunjukkan efek negatif terhadap kesehatan induk ikan tuna sirip kuning.

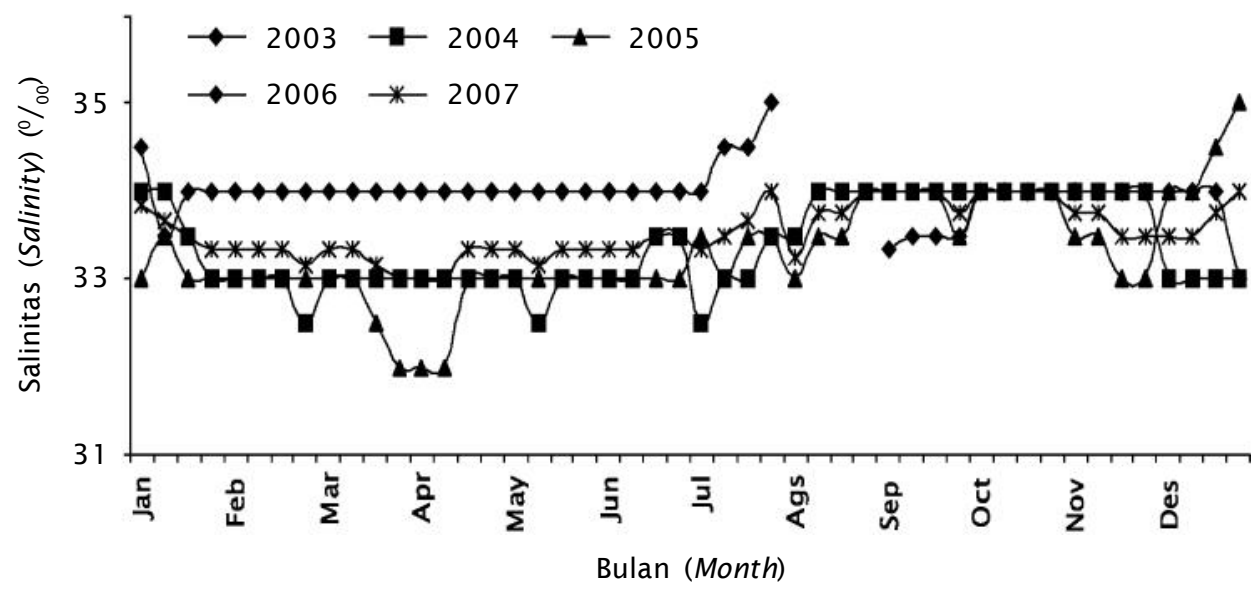

Gambar 4. Kondisi salinitas air laut dalam bak pemeliharaan induk ikan tuna sirip kuning (T. albacares) selama tahun 2003-2007

Figure 4. Water salinity variation in yellowfin tuna (T. albacares) broodstock tank during 2003 to 2007 


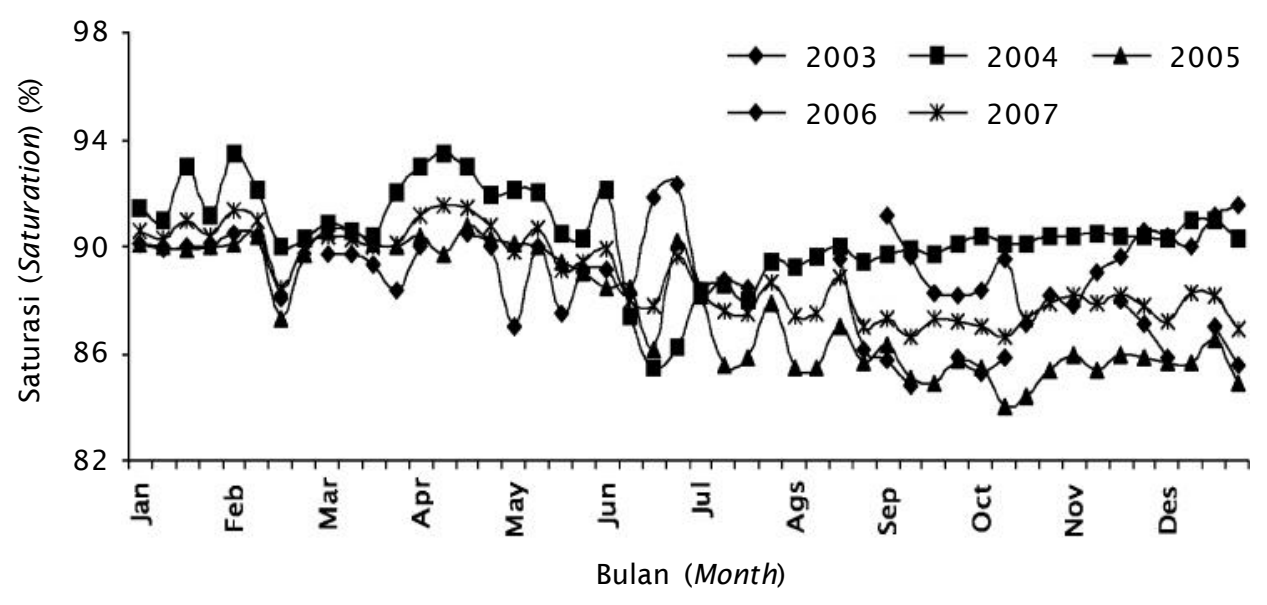

Gambar 5. Kondisi tingkat saturasi oksigen (\%) air laut dalam bak pemeliharaan induk ikan tuna sirip kuning (T. albacares) selama tahun 2003-2007

Figure 5. Percentage of oxygen saturation of water in yellowfin tuna (T. albacares) broodstock tank during 2003-2007

\section{Oksigen Terlarut}

Kandungan oksigen terlarut dalam air yang diukur pada saluran pembuangan air dari dalam bak disajikan pada Gambar 5. Nilai tingkat kejenuhan rata-rata berkisar antara 88\%-93\% yang setara dengan 5,5-5,8 mg/L. Berdasarkan pengalaman, jika blower dimatikan selama 1 jam, akan terjadi penurunan tingkat saturasi oksigen hingga 10\%. Untuk menjaga konsentrasi oksigen yang aman bagi ikan tuna, dianjurkan untuk menambahkan oksigen murni ke dalam air jika tingkat kejenuhan oksigen hanya mencapai $80 \%$ atau kurang dari 5 $\mathrm{mg} / \mathrm{L}$ (Wexler et al., 2003). Selain dengan menambahkan oksigen murni, apabila tingkat kejenuhan oksigen hanya sekitar $85 \%$, perlu dilakukan penambah aerasi sehingga tidak terjadi penurunan yang lebih drastis. Dianjurkan untuk melakukan pengecekan kandungan amoniak ketika kandungan oksigen di dalam air mengalami penurunan untuk dapat mengetahui penyebab penurunan oksigen tersebut dan juga untuk mencegah pengaruh negatif amoniak pada saat oksigen rendah.

\section{pH}

Pada umumnya, air laut mempunyai $\mathrm{pH}$ yang relatif stabil, namun ketika masuk ke dalam suatu sistem budidaya, beberapa input yang digunakan dalam sistem tersebut dapat menyebabkan penurunan $\mathrm{pH}$ air. Dalam pemeliharaan induk ikan tuna ini, selain induk ikan itu sendiri, input yang diberikan berupa pakan dan vitamin ditambah dengan sistem pergantian air yang semi tertutup, sangat memungkinkan terjadinya penurunan $\mathrm{pH}$ air. Pengukuran $\mathrm{pH}$ yang dilakukan setiap hari diperoleh hasil rata-rata $\mathrm{pH}$ bulanan seperti tertera pada Gambar 6.

Secara umum terlihat adanya perbedaan pH air dari tahun ke tahun, pada tahun 20032004 umumnya nilai pH air berada di atas nilai 8 yang merupakan ciri khas air laut. Namun pada tahun-tahun berikutnya ada kecenderungan penurunan $\mathrm{pH}$, terutama pada bulan Januari hingga April terlebih pada tahun 2005. Penurunan $\mathrm{pH}$ ini, diduga terjadi karena pada bulan tersebut adalah musim penghujan sehingga diperkirakan input dari daratan ke lautan mengakibatkan peningkatan kesuburan laut dan penurunan nilai $\mathrm{pH}$. Disamping itu, penambahan input ke dalam bak induk, baik akibat peningkatan jumlah dan biomassa induk serta penambahan pakan dari tahun ke tahun juga memberikan pengaruh terhadap perubahan $\mathrm{pH}$ rata-rata di dalam bak terutama setelah induk-induk memijah sehingga input tambahan berupa telur kemungkinan juga memberikan pengaruh terhadap penurunan $\mathrm{pH}$ air dalam bak induk.

\section{Suhu Air}

Pengukuran suhu air dalam bak induk dengan interval 30 menit menggunakan data 


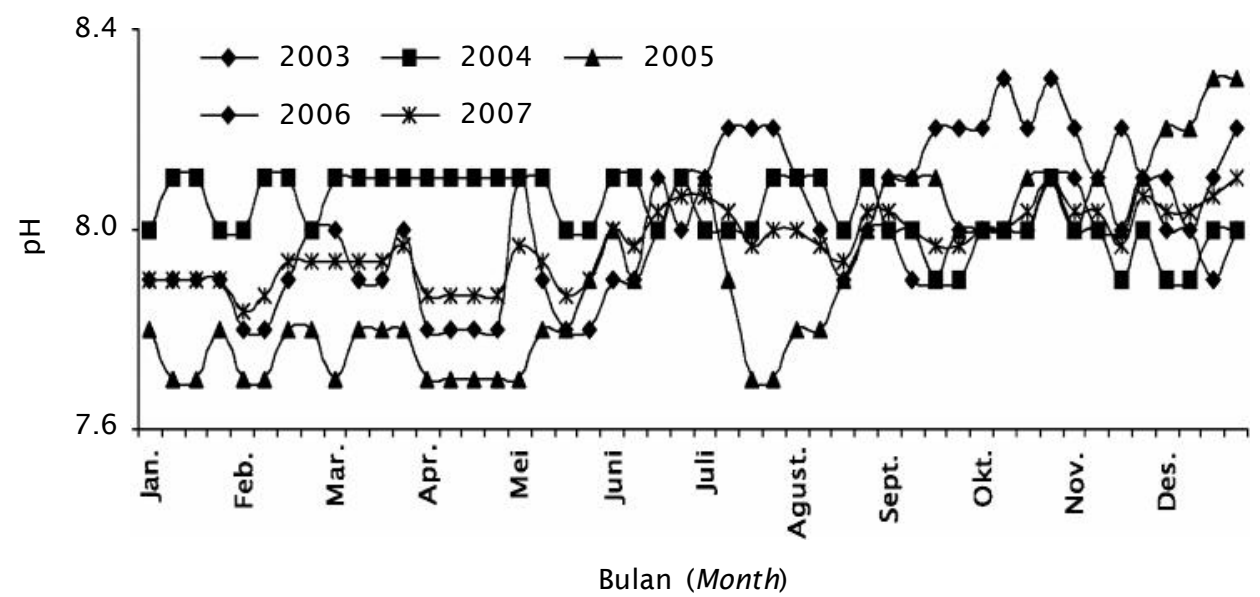

Gambar 6. Kondisi pH air laut dalam bak pemeliharaan induk ikan tuna sirip kuning ( $T$. albacares) selama tahun 2003-2007

Figure 6. $\quad \mathrm{pH}$ value of water in yellowfin tuna (T. albacares) broodstock tank during 2003-2007

logger (SK-L200T, Sato Keiryoki MFG.Co.LTD, Japan) selama tahun 2004-2008. Pola sebaran suhu relatif sama walaupun nilai suhunya sedikit berbeda. Suhu air tertinggi terjadi pada bulan April-Mei yaitu bertepatan dengan awal musim kemarau, kemudian suhu air menurun hingga bulan September yaitu pada puncak musim kemarau dan meningkat lagi hingga bulan Desember memasuki musim hujan. Namun ada kecenderungan bahwa suhu air

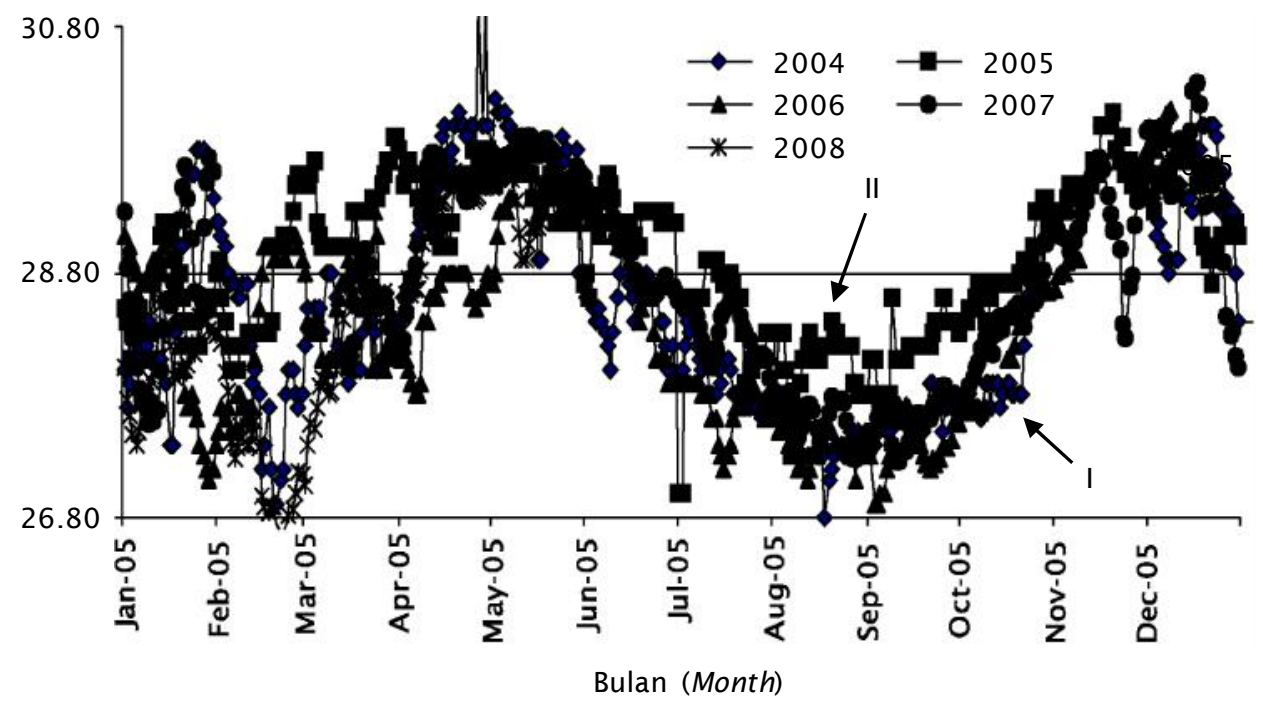

Gambar 7. Kondisi suhu air laut dalam bak pemeliharaan induk ikan tuna sirip kuning ( $T$. albacares) selama tahun 2003-2008 (I: awal pemijahan tahun 2004 \& II: awal pemijahan tahun 2005)

Figure 7. Water temperature variation in yellowfin tuna (T. albacares) broodstock tank during 2003-2008. (I: initial spawning period in 2004 \& II: initial re-spawning in 2005) 
dalam bak induk selama tahun 2005 cenderung lebih tinggi dari tahun-tahun lainnya seperti terlihat pada Gambar 7.

Ditinjau dari pola sebaran suhu, pemijahan induk ikan tuna sirip kuning dalam bak pemeliharaan terjadi ketika pola suhu air yang menurun dan kemudian diikuti peningkatan suhu. Pola seperti ini terjadi pada bulan Oktober 2004, Agustus 2005, dan Juni 2006 yang bertepatan dengan pemijahan induk. Berdasarkan pola suhu tersebut, maka pemijahan induk pada tahun 2007 diperkirakan terjadi pada bulan Juni atau Agustus. Namun pemijahan induk terjadi pada bulan Maret sebanyak 3 kali, April satu kali dan Juni 2 kali. Hal ini tidak mengikuti pola-pola pemijahan sebelumnya dan ternyata pola sebaran suhu di tahun 2007 juga lebih berfluktuasi dibandingkan dengan tahun-tahun lainnya.

Pemijahan ikan tuna di alam lebih dipengaruhi suhu perairan. Pemijahan terjadi jika suhu perairan di atas $24^{\circ} \mathrm{C}$. Hasil penelitian yang didapat dari proyek riset perbenihan ikan tuna sirip kuning di Panama dengan fasilitas yang sama menunjukkan bahwa pemijahan terjadi setelah suhu perairan menurun hingga $23^{\circ} \mathrm{C}$ lalu meningkat dan ketika mencapai $26^{\circ} \mathrm{C}$ ikan tuna mulai memijah (Wexler et al., 2003). Namun demikian, suhu air pemeliharaan induk dalam penelitian ini tidak pernah turun sampai sedemikian rendah. Pola yang mirip sama terlihat dimana suhu air mengalami penurunan lalu kemudian meningkat dan ternyata hal ini telah mampu merangsang induk-induk tersebut memijah (Gambar 7).

\section{Pengamatan Tingkah Laku Pemijahan Induk}

Tanda-tanda pemijahan pertama terlihat ketika induk betina berenang secara beraturan ke satu arah diikuti oleh 3-4 ekor induk jantan. Aktivitas ini dimulai pada pagi hari selama 15 menit lalu induk-induk tersebut kembali berenang seperti biasa. Pada siang hari hal tersebut juga terjadi sekitar 15 menit, lalu induk-induk tersebut berenang secara berpasangan. Satu betina dikejar oleh satu jantan selama lebih kurang 15 menit lalu berenang normal kembali. Dalam keadaan berenang berpasangan, induk betina tidak mengalami perubahan warna sementara induk jantan kelihatan menjadi lebih gelap sehingga terlihat jelas strip vertikal berwarna perak sepanjang tubuhnya dan warna pucat (putih) pada pangkal ekor. Tingkah laku seperti ini diperlihatkan setiap hari dengan intensitas yang semakin tinggi. Setelah 5 hari berturutturut kejadian tersebut terjadi, maka pada hari keenam terjadilah pemijahan pertama. Pemijahan ikan tuna dalam bak terjadi secara berpasangan, setelah sepasang induk berenang mengelilingi bak dengan kecepatan yang semakin tinggi dan kemudian merubah arah secara cepat ke permukaan atau ke arah dasar bak lalu memijah. Hal ini tidak seperti pada ikan bandeng atau kerapu yang dilaporkan memijah dalam bentuk group (Prijono et al., 1998; Tridjoko et al., 1996; Slamet \& Tridjoko, 1997). Demikian juga dengan waktu pemijahan, pada ikan kerapu dan kakap, umumnya pemijahan terjadi pada malam hingga pagi hari namun pada ikan tuna terjadi pada sore hari.

Setelah terjadi pemijahan, telur-telur akan terbawa ke bak pengumpul telur (kolektor telur) yang telah dipasang dengan saringan telur berukuran $95 \mathrm{~cm} \times 60 \mathrm{~cm} \times 70 \mathrm{~cm}$ yang terbuat dari kain katun dengan ukuran mata jaring 250$300 \mu \mathrm{m}$. Jaring dipasang dalam bak pengumpul telur siang hari dan dilakukan pembersihan pada pagi hari berikutnya. Pengecekan telur dilakukan setiap jam antara pukul 15.00-21.00 untuk memastikan ada tidaknya induk yang memijah.

Telur hasil pemijahan diambil secepat mungkin untuk keperluan pengamatan tingkat pembuahan dan perkembangan embrio. Berdasarkan tingkat perkembangan embrio tersebut dapat diperkirakan waktu yang dibutuhkan dari pemijahan hingga perkembangan satu sel. Selanjutnya data tersebut dapat digunakan sebagai standar penentuan waktu pemijahan. Pengambilan gambar telur juga dilakukan untuk keperluan pengukuran diameter telur dan butiran minyak.

Ukuran induk yang memijah pada penelitian ini diperkirakan lebih dari 9-10 kg atau panjang cagak lebih dari 82,2 cm dengan perkiraan umur sekitar 2 tahun (Permana et al., 2009, Unpublish). Hal ini hampir sama dengan apa yang diperoleh IATTC di Panama di mana ukuran induk pertama kali memijah adalah dari kelompok induk berukuran 6-16 kg atau panjang cagak antara 65-93 cm (Wexler et al., 2003) dan berdasarkan analisis mt-DNA telur dan larva dapat dipastikan bahwa induk yang memijah diperkirakan berukuran antara 12-28 $\mathrm{kg}$ atau 75-112 cm dengan umur sekitar 2 tahun (Niwa et al., 2003). Menurut Wild (1986) dalam Block \& Steven (2001), sebanyak 50\% ikan tuna 


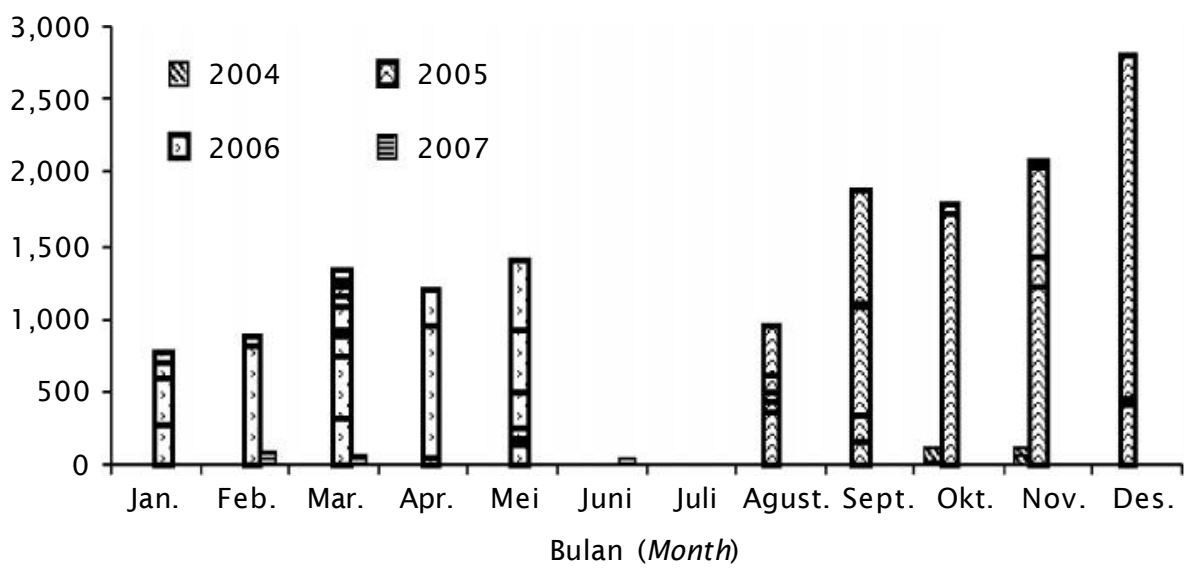

Gambar 8. Jumlah produksi telur (x 1.000) induk ikan tuna sirip kuning (T. albacares) secara alami dalam bak secara terkontrol selama tahun 2004-2007

Figure 8. Total egg production (x 1.000) of yellowfin tuna (T. albacares) broodstock in captivity during $2004-2007$

sirip kuning telah mencapai dewasa pada ukuran panjang cagak $69 \mathrm{~cm}$ atau berumur 2 tahun.

Pemijahan pertama ikan tuna sirip kuning yang dipelihara dalam bak beton terjadi pada bulan Oktober 2004 selama 10 hari berturutturut lalu kemudian berhenti dengan jumlah telur berkisar antara 7.000-122.000 butir. Pemijahan kedua terjadi pada tanggal 15 Agustus tahun 2005 dan hingga akhir Desember tercatat sebanyak 125 kali pemijahan. Ini berarti induk memijah hampir setiap hari, di mana satu ekor induk dapat memijah beberapa hingga berpuluh kali dalam masa pemijahan ini. Pemijahan ini terus berlanjut di tahun 2006 mulai Januari-Mei dan bulan Juli sebanyak 126 kali. Jika dilihat dari jumlah telur yang dihasilkan yaitu 550.000 ; 91.567.000; 75.427.000; dan 347.000 dari masing-masing tahun 2004, 2005, 2006, dan 2007 maka dapat dikatakan bahwa puncak produktivitas induk terdapat pada tahun 20052006.

Dalam tahun 2005, induk memijah sejak 15 Agustus dan hingga akhir bulan Desember sebanyak 125 kali dengan jumlah telur yang dibuahi per pemijahan berkisar antara 15.0002.074.000 dengan rata-rata 910.000 butir. Menurut Schaefer (1998), satu ekor induk ikan tuna sirip kuning secara teoritis dapat memproduksi telur dari 160.000 hingga 8.000 .000 butir per pemijahan, yang disimpulkan berdasarkan ikan tuna hasil tangkapan di alam. Hal ini mungkin terlalu tinggi dari kenyataan yang diperoleh pada penelitian ini.

Berdasarkan hasil pengamatan tahun 2008, pemberian hormon tidak efektif dalam memacu pemijahan induk tuna. Tidak ada peningkatan tanda-tanda pemijahan walaupun induk telah mulai memijah pada bulan Juli. Pemijahan induk terjadi pada pagi hari yang juga berbeda dari tahun sebelumnya dimana pemijahan terjadi pada sore hari, jumlah telur sangat sedikit dan rendahnya tingkat pembuahan telur. Ada dua kemungkinan yang menyebabkan hal ini, induk yang bertelur adalah induk-induk baru dan untuk pertama kalinya atau kematian induk yang pada umumnya berkelamin jantan sehingga jumlah induk jantan menjadi sangat terbatas sementara induk-induk betina sudah sangat matang gonad. Hal ini dapat dipastikan berdasarkan pengamatan telur yang dihasilkan induk-induk betina adalah telur-telur yang kuning telurnya telah diserap kembali (absorb) dan bentuknya yang sudah tidak bulat. Telurtelur ini diperkirakan telah lewat matang (over ripe) dan secara otomatis atau terpaksa harus dikeluarkan oleh induk betina.

\section{KESIMPULAN}

Ikan tuna sirip kuning (Thunnus albacares) dapat memijah secara alami dalam bak beton. Pemijahan umumnya berlangsung pada sore hari secara berpasang-pasangan dan puncak pemijahan terjadi pada tahun 2005 dan 2006 
dengan frekuensi pemijahan masing-masing lebih dari 100 kali, dengan jumlah induk berkisar antara 25-30 ekor.

Jumlah optimum induk untuk pemijahan adalah lebih dari sepuluh ekor. Jumlah induk yang terlalu sedikit atau ukuran yang terlalu besar berpengaruh negatif terhadap pemijahan induk.

Suhu air mempunyai pengaruh yang sangat besar terhadap tingkah laku pemijahan ikan tuna sirip kuning dalam bak.

\section{SARAN}

Mengingat bahwa kematian induk akibat menabrak dinding masih sering terjadi, maka perlu dilakukan pengadaan calon induk secara berkesinambungan untuk peremajaan induk dan menjaga jumlah induk yang optimum atau pemeliharaan induk dalam sistem karamba jaring apung.

\section{UCAPAN TERIMA KASIH}

Riset ini terlaksana atas dana kerja sama Riset dengan OFCF Jepang (2003-2006) dan APBN T.A. 2004-2008 yang dalam pelaksanaan penelitian ini dibantu oleh teknisi pelaksana. Untuk itu, ucapan terima kasih disampaikan kepada Gunawan, S.Pi., Ketut Sutaryasa, Jafar Shodiq, Putu Arta Sudarsana, dan Kadek Ardhika yang telah banyak membantu dalam pelaksanaan riset ini.

\section{DAFTAR ACUAN}

Anonimous. 2005. Press Release. Saving the bluefin tuna-First successful in-vitro fertilization of tuna eggs from captive stock. Reproduction and Domestication of Thunnus thynnus (REPRODOTT), $5 \mathrm{pp}$.

Batubara, H.M.P. 2003. Kajian potensi ikan tuna berdasarkan realisasi hasil tangkapan kapal Tuna long line PT Perikanan Samodra Besar. Lokakarya Pengkajian Stok Sumberdaya Ikan Nasional. Jakarta 25 Maret 2003. MPN, DKP dan ISPIKANI, $9 \mathrm{hlm}$.

Farwell, C.J. 2001. Tunas in Captivity. In: Block, B.A. and E.D. Stevens. Tuna: Physiology, Ecology and Evolution. Academic Press, p. 391-412.

Hutapea, J.H., Permana, I G.N., \& Nakazawa, A. 2003. Preliminary study of Yellowfin Tuna, Thunnus albacares capture for candidate broodstock. Prosiding International Seminar on Marine and Fisheries. 15-16 Dec. 2003, p. 29-31.
Hutapea, J.H. \& Permana, I G.N. 2007. Domestikasi calon induk ikan tuna sirip kuning (Thunnus albacares) dalam bak terkontrol. Buku Pengembangan Teknologi Budidaya Perikanan, hlm. 461-466.

Masuma, S. \& Oka, M. 1997. Rearing of Bluefin and Yellowfin Tuna in Sub-tropical areas. Proceeding of Fourth International Aquarium Congress. Tokyo, p. 67-70.

Margulies, D., Suter, J.M., Hunt, S.L., Olson, R., Scholey, V.P., Wexler, J.B., \& Nakazawa, A. 2009. Spawning and early development of captive yellowfin tuna (Thunnus albacares). Fishery Bull., p. 1-4.

Niwa, Y., Nakazawa, A., Margulies, D., Scholey, V.P., Wexler, J.B., \& Chow, S. 2003. Genetic monitoring for spawning ecology of captive yellowfin tuna (Thunnus albacares) using mitochondrial DNA variation. Aquaculture, 218 : 387-395.

Permana, I G.N, Haryanti, \& Hutapea, J.H. 2009 (Unpublish). Profil pemijahan ikan tuna sirip kuning, Thunnus albacares dalam bak terkontrol dengan analisis mitochondria DNA (mt-DNA), $9 \mathrm{hlm}$.

Prijono, A., Setiadharma, T., Sumiarsa, G., \& Sugama, V. 1998. Pengaruh perbandingan jenis kelamin (Seks rasio) induk bandeng terhadap kualitas dan kuantitas telur. Prosiding Simposium Perikanan Indonesia II. Ujung Pandang, 2-3 Desember 1997, hlm. 209-213.

Slamet, B. \& Tridjoko. 1997. Pengamatan pemijahan alami, perkembangan embrio dan larva ikan kerapu batik, Epinephelus microdon dalam bak terkontrol, J. Pen. Perik. Indonesia, III(4): 40-50.

Schaefer, K.M. 1998. Reproductive Biology of Yellowfin Tuna (Thunnus albacares) in the Eastern Pacific Ocean. Inter-American Tropical Tuna Commission. La Jolla, California. Bull., 21 (5): 272 pp.

Tridjoko, Slamet, B., Makatutu, D., \& Sugama, K. 1996. Pengamatan pemijahan dan perkembangan telur ikan kerapu bebek (Cromileptes altivelis) pada bak secara terkontrol. J. Pen. Perik. Indonesia, II(2): 5562.

Wexler, J.B., Scholey, V.P., Olson, R.J., Mergulies, D., Nakazawa, A., \& Suter, J.M. 2003. Tank culture of yellowfin tuna, Thunnus albacares: developing a spawning population for research purposes. Aquaculture, 220: 327-353. 